\title{
MACROECONOMICS AFTER COVID-19 PANDEMIC
}

\author{
Prof. (Dr.) Vishwajeet V. Jituri ${ }^{* 1}$ 吸 \\ ${ }^{* 1}$ Echelon Institute of Technology Faridabad, Haryana, India
}

DOI: https://doi.org/10.29121/granthaalayah.v8.i7.2020.581

Article Type: Research Article

Article Citation: Prof. (Dr.)

Vishwajeet V. Jituri. (2020).

MACROECONOMICS AFTER COVID-

19 PANDEMIC. International Journal of Research -GRANTHAALAYAH, 8(7), 38-45.

https://doi.org/10.29121/granthaa

layah.v8.i7.2020.581

Received Date: 25 June 2020

Accepted Date: 24 July 2020

Keywords:

Macroeconomics

Economy

3-Sector Economy

4-Sector Economy

Covid-19

Pandemic

Foreign Sector

Trade

\begin{abstract}
Macroeconomics concerns with total income, employment, investment etc. at countries level. The modern economy follows 4-sector model; wherein there is engagement of household sector, firms sector, government sector and the foreign sector. The volume of exports and imports of a country in percentage of its GDP gives indication of their exposure to the foreign sector. Post Covid-19, there is tendency of many countries to follow 3-sector economic model and reduce their dependency on the foreign sector. This paper does overview of the economic models in view of the pandemic Covid-19.
\end{abstract}

\section{INTRODUCTION}

Economics is a social science that seeks to analyze and describe the production, distribution, and consumption of wealth. It portrays the flow of money, goods, and services in an industrial economy. The aim is to study the forces determining prices of goods, services and the resources used to produce them. This involves the discovery of two key elements: what governs the way in which human labour, machines, and land are

combined in production and how buyers and sellers are brought together in a functioning market. Because prices of the various things must be interrelated, the question is how 'price system' or 'market mechanism' relate to each other and the conditions necessary for its survival. (Blaug, n.d.)

There are two branches of economics. The Microeconomics is the part of economics that deals with the behaviour of individual entities such as consumers, business firms, traders, and farmers. The other is Macroeconomics, which focuses attention on aggregates such as the level of income in the whole economy, the volume of total employment, the flow of total investment, and so forth. The Macroeconomics is concerned with the

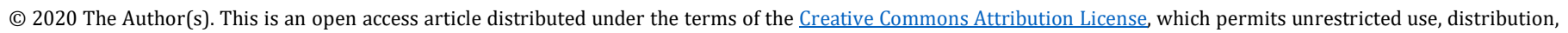
and reproduction in any medium, provided the original author and source are credited. 
forces determining the income of a country or the level of total investment and about learning which public policies would help a country to achieve higher or full employment and greater price stability. (Blaug, n.d.)

The macroeconomics involve four sectors; namely household sector, firms sector, government sector and the foreign sector. A brief description of the four sectors is given in Table 1. (Singh, Tanjot;)

Table 1

\begin{tabular}{|c|c|}
\hline $\begin{array}{l}\text { Household } \\
\text { sector }\end{array}$ & $\begin{array}{l}\text { This sector includes all the individuals in the economy. The primary function of this sector is to } \\
\text { provide the factors of production. The factors of production include land, labour, capital and } \\
\text { enterprise. The household sectors are the consumers who consume the goods and services } \\
\text { produced by the firms and in return make payments for the same. }\end{array}$ \\
\hline Firms sector & $\begin{array}{l}\text { This sector includes all the business entities, corporations and partnerships. The primary } \\
\text { function of this sector is to produce goods and services for sale in the market and make factor } \\
\text { payments to the household sector. }\end{array}$ \\
\hline $\begin{array}{l}\text { Government } \\
\text { sector }\end{array}$ & $\begin{array}{l}\text { This sector includes the central, state, and local governments. The prime function of this sector } \\
\text { is to regulate the functioning of the economy. The government sector incurs both revenue as } \\
\text { well as expenditure. The government earns revenue from tax and non-tax sources and incurs } \\
\text { expenditure for providing essential public services to the people. }\end{array}$ \\
\hline $\begin{array}{l}\text { Foreign } \\
\text { sector }\end{array}$ & $\begin{array}{l}\text { This sector includes transactions with the rest of the world. Foreign trade implies net exports } \\
\text { (exports minus imports). Exports include goods and services produced domestically and sold to } \\
\text { the rest of the world and imports include goods and services produced abroad and sold } \\
\text { domestically. }\end{array}$ \\
\hline
\end{tabular}

The interrelationship between the four sectors depicts the working of an economy and circular flow of income in a country or countries or world as a whole. Depending upon the interdependence of sectors on each other, there are three models of circular flow of income in an economy; two (2) sector model, three (3) sector model and four (4) sector model. (Shared by Mukherjee)

Two sector model: The 2-sector model involves household sector and firms sector only. The households provide resources such as land, capital and entrepreneurial ability to the business firms. As a result, the money flows from business firms to the households as factor payments such as wages, rent, interest and profits. This money flows back from households to the firms as consumption expenditure made by them on the goods and services produced by the firms. This completes the loop of circular flow of income as shown in Figure 1.

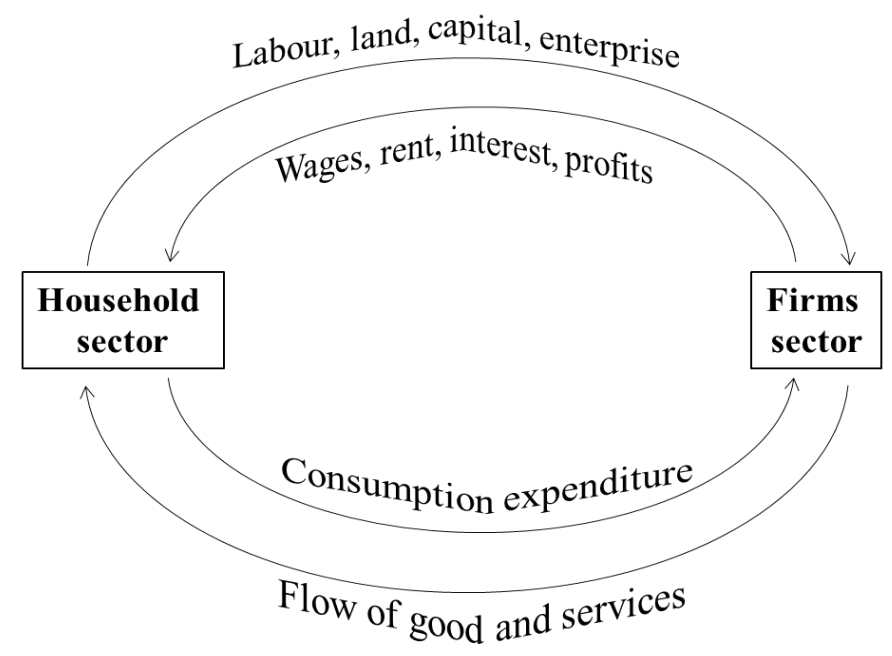

Figure 1: (Source: www.economicsdiscussion.net/)

In the 2-sector model, the assumption that the households spend all their earned income to buy goods and services is a simple way of representing the circular flow of income. In reality, the households save some of their income and as such this is called leakage from the total income of the economy. However, if the households invest their savings in the financial market, then it comes back into the circular flow of the income. 
Three sector model: The 3-sector model includes government as another sector, besides the household and firms sectors. The government affects the economy in a number of ways. It absorbs a good part of the incomes in the form of taxes and other levies. The government also purchases goods and services like households and the firms. The government expenditure takes many forms including spending on capital goods and infrastructure (highways, power, communication), on defence goods, and on education and public health etc. Also, it may pump investments in the income, in order to fill the gap left by the leakage income. The Figure 2 depicts the 3-sector model of economy.

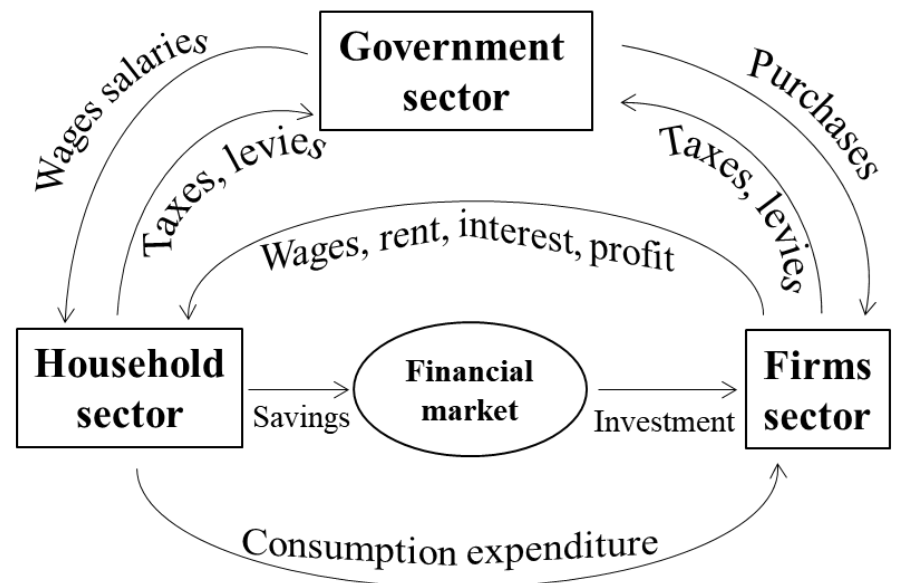

Figure 2: (Source: www.economicsdiscussion.net/)

The 3-sector model assumes closed economy of a country. However, in modern and open economy, the countries are engaged in import and export activities also, thereby involving the foreign sector. Besides the import and export, the foreign sector may do significant investments in a country.

Four sector model: The 4-sector model includes foreign sector and there are trade relations with foreign countries. The foreign firms interact with the domestic firms and households through export and import of goods and services. Also, the foreign sector gets involved in borrowing and lending operations in a country through financial market. The goods and services produced within the domestic territory which are sold to the foreigners are called exports. The Figure 3 shows a typical 4-sector model of economy.

(Shared by Mukherjee)

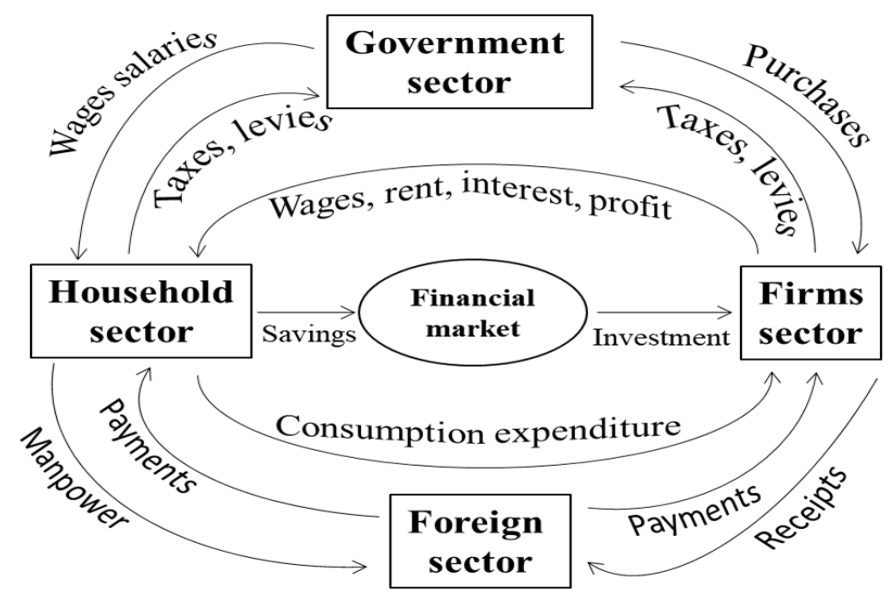

Figure 3: (Source: www.economicsdiscussion.net/)

While 2-sector and 3-sector models are closed economic models, meaning that rest of the world is cut-off from the country; the 4-sector model is open economic model and is most prominent today. That means that besides domestic production and consumption, the countries are also involved in exports and imports of goods, services, financial instruments etc. Most of the countries are not self-sufficient to be able to produce or consume all the goods 
required by them. These could be raw material, oil, finished goods, financing etc. Due to this, they are dependent upon the other countries to fulfil their requirements and/or to contribute in their economic development. The open trade in the world market makes this possible.

There are advantages and disadvantages of 4-sector economy, i.e. involvement of the foreign sector in the country's economy. The advantages include access to new customers, lowering cost, availability of finances, diversification of business risk, availability of foreign products, availability of production technology/ facilities, outsourcing of non-core activities, supply chain management, employment creation, reducing political risk etc. (Edwards, 2014)

Some of disadvantages of 4-sector (open) economy are risk exposure (disturbance in one country may have supply chain issue on the other countries), disproportionate size of the economy (when imports are too high as compared to the exports), financial instability (withdrawal by foreign investors), increase in international debt, reduction in domestic production, constraints on resource usage, problem of foreign exchange etc. (shared by Mehra, n.d.)

In an open economy, there is great importance of management of foreign exchange reserves. Foreign exchange reserves are the backbone of international reserves in most countries today and are the most frequently used and the largest in the international reserve assets. Foreign exchange reserves can be in the form of cash, cash and foreign currency financial assets or equity vouchers of convertible foreign currencies held by a government. In narrow sense, the foreign exchange reserves are an important part of a country's economic strength, the foreign exchange accumulation is used by a country to balance the payments, stabilize the exchange rate and repay the external debt. Broadly speaking, the foreign exchange reserves refer to foreign exchange-denominated assets, including cash, foreign bank deposits and the foreign securities. (Du, Lin, \& Han, 2018)

The foreign exchange reserves are important means for a country to carry out economic regulation and achieve internal and external balance. For the international balance of payments, the use of foreign exchange reserves can promote the balance of payments. If there is domestic macroeconomic imbalance due to total demand being greater than the total supply, the country can use foreign exchange to import, thus regulating the total supply and the relationship between aggregate demand; in order to promote the macroeconomic balance. Also, at time exchange rate fluctuations due to some disturbance, the foreign exchange reserves can be utilized to intervene and stabilize the exchange rate. Therefore, the foreign exchange reserves are indispensable instruments of achieving economic equilibrium and stability, especially in the context of continuous development of economic globalization and the fact that a country's economy is more vulnerable to economic impact from other countries. (Du, Lin, \& Han, 2018)

\section{MACROECONOMICS BEFORE COVID-19}

On overall basis, the total export products for the world in the year 2019 are estimated at US\$ 18.74 trillion. This is 13.4 per cent increase over the 5-year period starting from 2015, but is 3.7 per cent less than the total world export in 2018 standing at US\$ 19.456 trillion. The top exporting countries along with their export value are given in Table 2. (Workman, 2020)

Table 2

\begin{tabular}{|c|c|c|}
\hline Sr.no. & Country & Export (US\$ trillion) \\
\hline 1 & China & 2.498 \\
\hline 2 & United States & 1.645 \\
\hline 3 & Germany & 1.486 \\
\hline 4 & Netherlands & 0.721 \\
\hline 5 & Japan & 0.705 \\
\hline 6 & France & 0.555 \\
\hline 7 & South Korea & 0.541 \\
\hline
\end{tabular}

The total Gross Domestic Product (GDP) for all countries totalled at \$135.178 trillion 2018. So, around 14.4 per cent of the world's GDP was contributed by the foreign sector. The top 20 exporting countries accounted for 72 per cent of the total exports. (Workman, 2020) 
In comparison, India did total exports of US\$313.34 billion in 2019. The prominent countries to whom the exports were made were U.S.A (17\%), UAE (9.2\%), China (5.3\%), Hongkong (3.5\%), Netherlands (2.7\%), Singapore (2.8\%), U.K (2.8\%), Germany (2.6\%) and Bangladesh (2.4\%). (Department of Commerce, n.d.)

The total imports in India in 2019 amounted to US\$ 473.98 billion. The major countries were China (13.8\%), U.S.A (7.5\%), UAE (6.4\%), Saudi Arabia (5.7\%), Iraq (5\%), Hongkong (3.6\%), Sweden (3.6\%), South Korea (3.3\%), Indonesia (3.2\%), Singapore (3.1\%), Germany (2.8\%) and Japan (2.6\%). (Department of Commerce, n.d.)

There are many countries who have high percentage of their imports and exports in comparison with their GDP. Some of these are given as per year 2016 data in Table 3. (OECD, n.d.)

Table 3

\begin{tabular}{|c|c|c|c|}
\hline Sr.no. & Country & Imports as percentage of GDP & Exports as percentage of GDP \\
\hline 1 & Luxembourg & $177.6 \%$ & $213 \%$ \\
\hline 2 & Ireland & $105.2 \%$ & $120.8 \%$ \\
\hline 3 & Belgium & $78.2 \%$ & $79.4 \%$ \\
\hline 4 & Czech Republic & $71.8 \%$ & $79.6 \%$ \\
\hline 5 & Netherlands & $69.3 \%$ & $79.5 \%$ \\
\hline 6 & European Union & $40.3 \%$ & $43.8 \%$ \\
\hline 7 & Germany & $38.7 \%$ & $46 \%$ \\
\hline 8 & India & $21 \%$ & $19.3 \%$ \\
\hline 9 & China & $17.4 \%$ & $19.6 \%$ \\
\hline 10 & United States & $14.6 \%$ & $12.5 \%$ \\
\hline
\end{tabular}

Why do countries import? In the present times, no country can be totally self-sufficient, either due to lack of resources or without suffering a high cost. Even the United States, which has massive and extraordinarily diverse economy imports from other countries. In fact, there are only a handful of goods or services that the United States absolutely must import from other countries. With a land area spanning several climatic zones, immense natural resources, and a dynamic workforce, the United States can produce, mine, or grow almost every item which its citizens need to lead prosperous lives. The United States has almost entirely stopped producing some goods because of foreign competitive efficiency. The firms in other countries are able to produce these goods faster, cheaper, and may be of better quality. (Levin Institute, n.d.)

The imports in a country is done for many purposes; e.g. it could be as raw material, semi-finished material, intermediate material, technology, finished goods, essential goods etc. While the United States is doing imports for certain reasons, most of the other countries in 4-sector economic model are entangled in the web of imports and exports in such a manner that in case of any major disturbance in the world economy, the ripples and effects are felt in all the countries. Such a situation has now risen due to Covid-19.

The Covid-19 emerged in China as an epidemic near the end of year 2019 and in a span of few months, it wrapped the whole world becoming a pandemic. As a result, various countries went into a cycle of lockdown and restrictions, seriously affecting the production of goods, movement of people and availability of the goods. Now, dependence on the foreign sector is becoming clear to the countries with bottlenecks or supply chain issues being created in the creation of their own GDP.

In India too, many sectors are heavily dependent on imports right now and cannot be immediately produced domestically. Some of such products are electrical equipment, smartphones $(88 \%$ of the components used by the mobile handsets industry are imported from countries like China), computers, printed circuit boards (PCBs), primary and critical components of machinery, medical devices (60\% are imported), solar power cells, key ingredients for antibiotics and vitamins (INR 249 billion worth of key ingredients were imported in 2019, which accounted for approximately $40 \%$ of the overall domestic consumption), auto components, chemicals, dyes and dyestuff (nearly $20 \%$ of India's dyes and dyestuff industry production was hit due to a disruption in raw material supply from China due to Covid-19), crude oil etc. (Raghavan \& Singh, 2020)

Looking into such difficulties, various countries are looking up to self-reliance and self-sufficiency. 
Macroeconomics After Covid-19 Pandemic

\section{MACROECONOMICS AFTER COVID-19}

The Indian Prime Minister has brought up the importance of local manufacturing and consumption of locally produced goods, stating that Indians needed to become "vocal for local". He indicated that the government would undertake major reforms for the Indian industry in order to become self-reliant and play a major role in the global supply chain.

India is currently trying to encourage domestic firms to make key ingredients [known as fermentation-based APIs (Active Pharmaceutical Ingredient)] in pharmaceutical industry. However, this exercise may take a few years.

India is not heavily dependent on imports for some products e.g. textile components like yarn, so the production of such products can be scaled up immediately.

While technology transfer is required for more advanced and critical medical devices, the country does have the capacity to domestically make products like hot water bottles, mercury thermometers, hypodermic needles, wheelchairs and patient monitoring display units.

The manufacturing of some key imported products like semiconductors, displays and other capital-intensive electrical equipment may not be possible on early basis, as manufacturing these requires large, stable sources of clean water and electricity besides high upfront investments. They also need a high degree of policy certainty as these are long term projects. The Indian firms can however begin producing less sophisticated components.

Also, a key issue holding back manufacturing in India is due to lack of flexibility in the labour laws, high costs and low availability of land and high cost of electricity. The government should work on making the industry efficient by having growth oriented industrial policies and making the infrastructure more efficient.

(Raghavan \& Singh, 2020)

The Covid-19 episode is likely to become an economic fallout for China make it somewhat weakened. Presently, China does not have the same fiscal and monetary firepower to deploy as it did after the financial crisis of 2008. Also, China would be dependent on recoveries in its major markets, especially the United States. The concerns about Covid-19 like issues recurring in future will push the other countries having strong capabilities towards greater selfreliance. The United States would strive to bring home production of critical items, or at least out-source them outside China - maybe to India. However, it is also felt that China could return more powerful as it has already restarted production lines and will have a lead in manufacturing. However, faulty items supplied by China for fighting the Covid-19 will dampen sentiments. (Ramesh, 2020)

The trend which became clear after 2008 global financial crisis was the rise of Asia. Till the 18th century, Asia used to account for half the global GDP. Later, the Industrial Revolution accompanied by European naval expansion and colonialism contributed to the rise of the Western countries. The Asian countries have also demonstrated greater agility in tackling the pandemic compared to the United States and Europe. Consequently, Asian economies will recover faster than those in the West. (Sood, 2020)

In recent years, the U.S.-China relationship has moved from cooperation to competition; and now with trade and technology wars, it is moving steadily to confrontation. The Covid-19 pandemic has accelerated the tension on both the sides and a partial economic de-coupling has begun and gathering greater momentum. (Sood, 2020)

After this unprecedented global health crisis caused by Covid-19, trade is essential to save lives and livelihoods; and international co-operation is needed to keep the trade flowing. Amid this significant uncertainty, the following points needs to be noted:

- Boost confidence in trade and global markets by improving transparency about trade-related policy actions and intentions.

- Keep supply chains flowing, especially for essentials such as health supplies and food

- Avoid making things worse, through unnecessary export restrictions and other trade barriers

- The governments support needs to be delivered in a manner to ensure that it serves the public interest and not vested interests and avoids becoming market distortions for the future.

(OECD, 2020)

After COVID-19 there is a risk that the world could be yet more divided, conflictual and nationalistic. The failure to cooperate internationally will hinder the fight against Covid-19. The closing down of trade, requisitioning materials, or preventing supply to other countries will hamper the growth of the countries. The closing of borders and snapping of international rules will make it even more difficult to restart the trade and travel. (Woods, 2020) 


\section{CONCLUSION}

In the introductory section; 2-sector, 3-sector and 4-sector (open) economic models were described. The literature review indicates that post Covid-19, the countries may try to become self-dependent and self-sufficient in future, to have less dependency or reduce sensitivity to the foreign sector. This would bring the countries' economic model closer to 3-sector economy, going away from the present 4-sector open economic model.

However, the task to turn towards 3-sector economy is not simple and involves lot of investment, implementation of long term policies, holding on international pressure, convincing the residents, possibility of boycott by other countries etc.; besides devoting a long period of time for restructuring the economy, wherein the future events/ results are uncertain.

\section{SOURCES OF FUNDING}

This research received no specific grant from any funding agency in the public, commercial, or not-for-profit sectors.

\section{CONFLICT OF INTEREST}

The author have declared that no competing interests exist.

\section{ACKNOWLEDGMENT}

None.

\section{REFERENCES}

[1] Blaug, M. (n.d.). Economics. Retrieved July 8, 2020, from www.britannica.com/topic/: https://www.britannica.com/topic/economics

[2] Department of Commerce. (n.d.). Export/Import: Country-wise. Retrieved July 9, 2020, from https://commerce-app.gov.in/: https://commerce-app.gov.in/eidb/

[3] Du, S., Lin, X., \& Han, X. (2018). Advantages and Disadvantages of Continued Growth in Foreign Exchange Reserves. Financial Statistical Journal, 8-13.

[4] Edwards, J. (2014). Advantages and Disadvantages of Competing in International Markets. In Mastering Strategic Management (1st ed.). BCcampus. Retrieved July 9, 2020, from https://opentextbc.ca/strategicmanagement/chapter/advantages-and-disadvantages-of-competing-ininternational-markets/

[5] Levin Institute. (n.d.). Why do Nations Import? Retrieved July 10, 2020, from www.globalization101.org/: http://www.globalization101.org/why-do-nations-import/

[6] OECD. (2020, June 12). COVID-19 and international trade: Issues and actions. Retrieved from www.oecd.org/: http://www.oecd.org/coronavirus/policy-responses/covid-19-and-international-tradeissues-and-actions-494da2fa/

[7] OECD. (n.d.). Trade in goods and services. Retrieved July 10, 2020, from https://data.oecd.org/: https://data.oecd.org/trade/trade-in-goods-and-services.htm

[8] Raghavan, P., \& Singh, K. (2020, May 14). Self-reliant India: Which sectors depend on imports, and which do not. Retrieved from https://indianexpress.com/: https://indianexpress.com/article/explained/self-reliantindia-which-are-the-sectors-dependent-on-imports-which-are-not-6408407/

[9] Ramesh, M. (2020, April 2). Post-Covid-19 world will be 'very different for China. Retrieved from www.thehindubusinessline.com/: https://www.thehindubusinessline.com/news/world/post-covid-19world-will-be-very-different-for-china/article31224016.ece\#

[10] shared by Mehra, U. (n.d.). 7 Disadvantages of Open Economy to a Country. Retrieved July 9, 2020, from www.shareyouressays.com/: https://www.shareyouressays.com/knowledge/7-disadvantages-of-openeconomy-to-a-country/103040 
[11] Shared by Mukherjee, S. (n.d.). Circular Flow of Income: 2 Sector, 3 Sector and 4 Sector Economy. Retrieved July 8, 2020, from https://www.economicsdiscussion.net/: https://www.economicsdiscussion.net/circularflow/circular-flow-of-income-2-sector-3-sector-and-4-sector-economy/10207

[12] Singh, Tanjot;. (n.d.). Basic Macroeconomics: Circular Flow of Income and Expenditure. Retrieved July 8, 2020, from http://epgp.inflibnet.ac.in/: http://epgp.inflibnet.ac.in/epgpdata/uploads/epgp_content/economics/basic_macroeconomics/02._circul ar_flow_of_income_and_expenditure/et/5380_et_02et.pdf
Sood,
$\mathrm{R}$.
$(2020$,
May 11).

www.thehindu.com/.

Retrieved from https://www.thehindu.com/opinion/lead/the-trends-shaping-the-post-covid-19world/article31552150.ece

[14] Woods, N. (2020, May). Global Governance: Planning for the World after COVID-19. Retrieved July 10, 2020, from http://www3.weforum.org/: http://www3.weforum.org/docs/WEF_Challenges_and_Opportunities_Post_COVID_19.pdf

[15] Workman, D. (2020, July 6). World's Top Export Countries. Retrieved from www.worldstopexports.com/: http://www.worldstopexports.com/worlds-top-export-countries/ 